\title{
Effects of lightning on reactive nitrogen and nitrogen reservoir species in the troposphere
}

\author{
Xuexi Tie, ${ }^{1}$ Renyi Zhang, ${ }^{2}$ Guy Brasseur, ${ }^{1.3}$ Louisa Emmons, ${ }^{1}$ and Wenfang Lei ${ }^{2}$
}

\begin{abstract}
The impact of lightning on tropospheric reactive nitrogen $\mathrm{NO}_{x}\left(\mathrm{NO}+\mathrm{NO}_{2}\right)$ and nitrogen reservoir species $\left(\mathrm{HNO}_{3}\right.$, peroxyacetyl nitrate (PAN), $\mathrm{N}_{2} \mathrm{O}_{5}$, and $\mathrm{HNO}_{4}$ ) has been evaluated using a global chemical/transport model. Comparison of calculations made with and without lightning show that lightning has a significant effect on the nitrogen species on a global scale, resulting in significant enhancements of $\mathrm{NO}_{r}, \mathrm{HNO}_{3}$, and $\mathrm{PAN}$ over the no lightning case. Of the nitrogen species, $\mathrm{HNO}_{3}$ is influenced the most, comprising approximately 60 to $80 \%$ of the total increase in the nitrogen species concentration. The increase in PAN accounts for approximately 20 to $30 \%$ of the nitrogen enhancement by lightning in the middle troposphere. In the lower troposphere of the tropics, $\mathrm{NO}_{r}$ is rapidly converted into $\mathrm{HNO}_{3}$ due to the high $\mathrm{OH}$ concentration in this region. As a result, the enhancement in $\mathrm{NO}_{x}$ from direct lightning emission is limited primarily to the upper troposphere. The conversion between $\mathrm{NO}_{x}$ and less reactive nitrogen species ( $\mathrm{PAN}$ and $\mathrm{HNO}_{3}$ ) also plays an important role in affecting $\mathrm{NO}_{x}$, especially over the oceans where lightning activity is low. The model results suggest that recycling of $\mathrm{NO}_{x}$ from the lightning-enhanced $\mathrm{PAN}$ and $\mathrm{HNO}_{3}$ produces 2 to 10 parts per trillion by volume (pptv) increases in $\mathrm{NO}_{x}$ over the oceans in the lower troposphere of the tropics. The enhancement of $\mathrm{NO}_{x}$ over the oceans can partially explain the observations of $\mathrm{NO}_{x}$ (mixing ratios of typically $10-50 \mathrm{pptv}$ ) over the tropical oceans, which are characterized by higher concentrations than would be expected from direct transport of $\mathrm{NO}_{x}$ from the continents.
\end{abstract}

\section{Introduction}

Ozone is produced in the troposphere by photochemical oxidation of hydrocarbons and $\mathrm{CO}$ catalyzed by hydrogen oxide radicals $\left(\mathrm{HO}_{\mathrm{x}}=\mathrm{OH}+\mathrm{HO}_{2}\right)$ and nitrogen oxide radicals $\left(\mathrm{NO}_{x}=\right.$ $\mathrm{NO}+\mathrm{NO}_{2}$ ). Consequently, changes in atmospheric $\mathrm{NO}_{x}$ concentrations can lead to a modification in the rate of ozone production [Crutzen, 1970]. $\mathrm{NO}_{x}$ is also intricately linked to the hydroxyl radical. The reaction between $\mathrm{HO}_{2}$ and $\mathrm{NO}$ facilitates $\mathrm{OH}$ formation, while the reaction between $\mathrm{NO}_{2}$ and $\mathrm{OH}$ leads to the formation of $\mathrm{HNO}_{3}$, which is a relatively stable nitrogen reservoir species. As a result, $\mathrm{NO}_{x}$ directly influences the oxidizing capacity of the atmosphere [World Meteorological Organization (WMO), 1995]. $\mathrm{NO}_{x}$ is emitted into the atmosphere from various natural and anthropogenic sources, including fossil fuel combustion, biomass burning, aircraft emission, and lightning [e.g., Brasseur et al., 1996; Seinfeld and Pandis. 1998]. The production of $\mathrm{NO}_{x}$ by lightning has been a subject of numerous studies [e.g., Liaw et al., 1990; Biazar and McNider, 1995; Price et al., 1997]. Estimates of the global $\mathrm{NO}_{x}$ production by lightning vary consuderably [e.g., Levine, 1981; Franzblau and Popp, 1989; Nesbitt et al., 2000]. In a recent study, it has been suggested that a

\footnotetext{
INational Center for Atmospheric Research, Boulder, Colorado.

${ }^{2}$ Department of Atmospheric Sciences, Texas A\&M University, College Station, Texas.

${ }^{3}$ Also at Max-Planck Institute for Meteorology, Hamburg, Germany.
}

Copyright 2001 by the American Geophysical Union.

Paper number 2000JD900565.

0148-0227/01/2000JD900565\$09.00 source strength in excess of $20 \mathrm{Tg} \mathrm{N} / \mathrm{yr}$ would yield modelcalculated mixing ratios of reactive nitrogen in the upper troposphere significantly larger than those typically observed [Lamarque et al., 1996]. However, even the $\mathrm{NO}_{\mathrm{r}}$ production in the range of $1-12 \mathrm{Tg} \mathrm{N} / \mathrm{yr}$ from lightning is still sufficient to allow for a significant difference in the large-scale model-predicted abundance of the reactive nitrogen and in the photochemical formation of ozone in the middle and upper troposphere.

A number of studies have been conducted to investigate the effects of lightning on the tropospheric chemucal constituents, especially on NO, and ozone concentrations [e.g., Lamarque et al.. 1996: Pickering et al., 1998]. For example, the model calculation by Lamarque et al. [1996] suggests that the $\mathrm{NO}_{x}$ concentration in the southern hemisphere is mostly dominated by the lightning source, while in the northem hemisphere the influence of lightning on $\mathrm{NO}_{\mathrm{r}}$ is significant, but less important than in the southern hemisphere. Field experimental data also support that the $\mathrm{NO}_{\mathrm{r}}$ concentrations are considerably enhanced when lightning is present [Ehhalt et al., 1992]. Airbone measurements in and near mature thunderstorms show that $\mathrm{NO}_{x}$ is increased by as much as a few ppb from lightning in the upper troposphere on small spatial scales [Ridley et al., 1996; Huntrieser et al., 1998; Stith et al.. 1999]. In addition, another recent study has found evidence between the enhancement of $\mathrm{NO}_{\mathrm{r}}$ in the upper troposphere and lower stratosphere and lightning activity [Zhang et al., 20001.

The typical lifetime of $\mathrm{NO}_{x}$ increases from a few hours in the planetary boundary layer to a few days in the upper troposphere in summer. Observations over the tropical oceans indicate free troposphere $\mathrm{NO}_{\mathrm{r}}$ mixing ratios of typically 10-50 parts per trillion by volume (pptv) [Carroll and Thompson, 1995; Emmons et al., 1997] which is higher than would be expected from direct transport of primary $\mathrm{NO}_{x}$ from the continents, indicating that 


\section{(JUNE)}

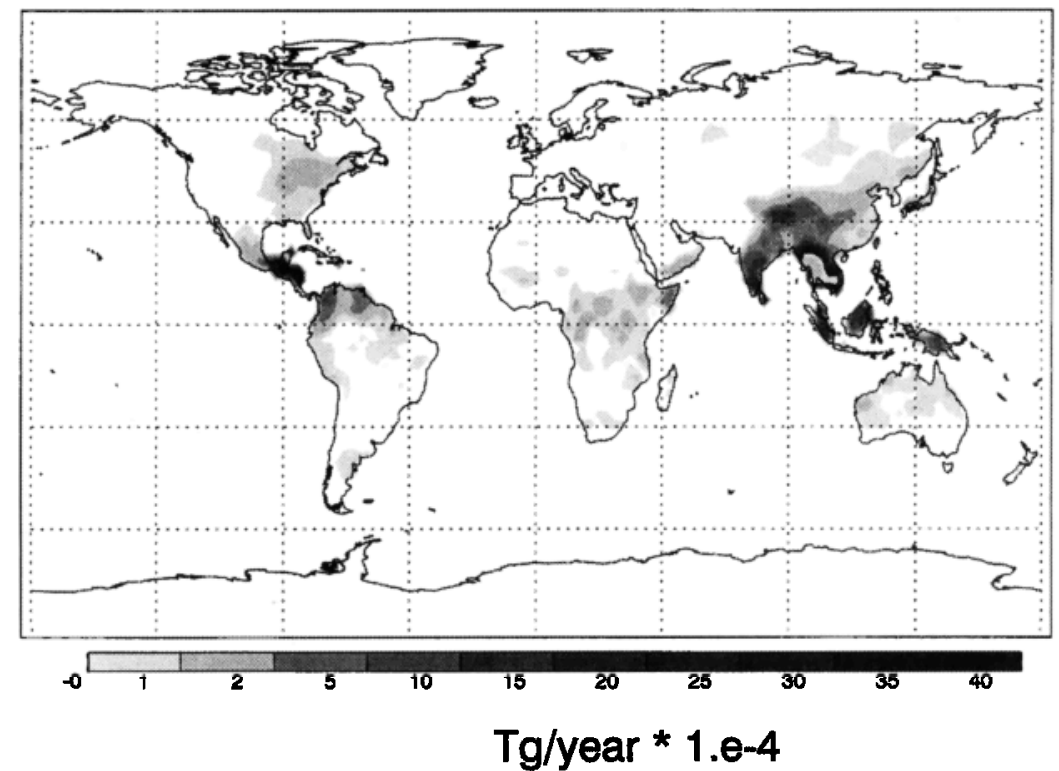

(DEC.)

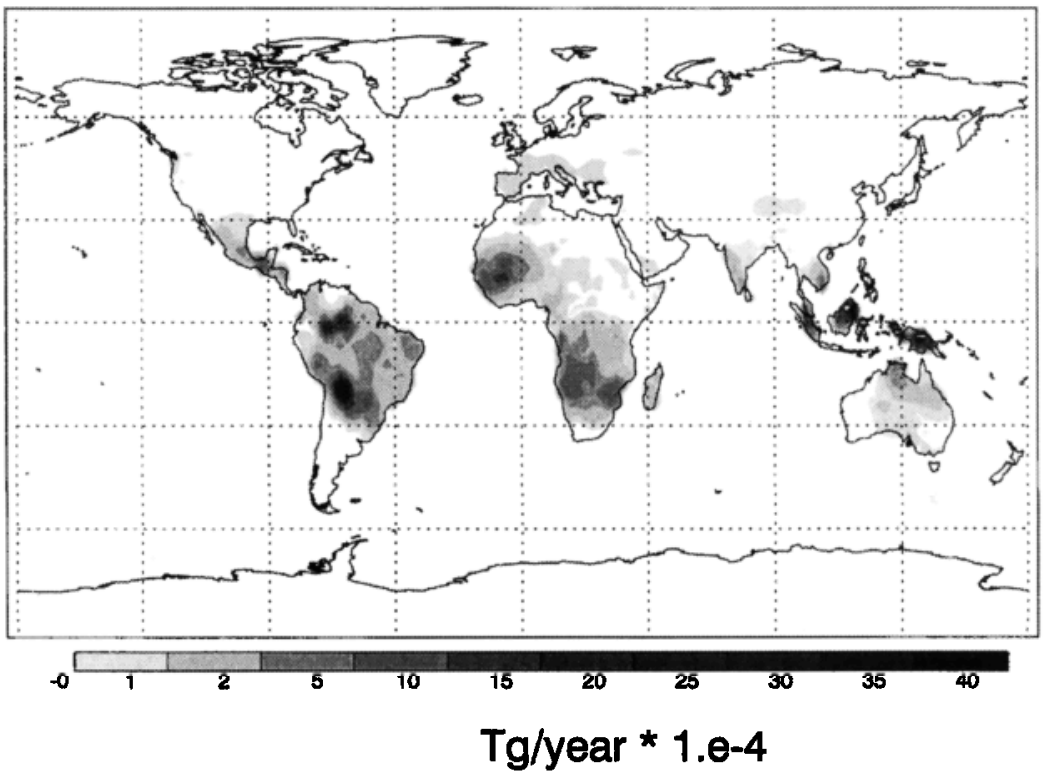

Figure 1. The global horizontal distribution of lightning $\mathrm{NO}_{x}$ emission used in the model for June and December.

chemical recycling of $\mathrm{NO}_{x}$ from $\mathrm{HNO}_{3}$ and peroxyacetyl nitrate (PAN) $\left(\mathrm{CH}_{3} \mathrm{CO}_{3} \mathrm{NO}_{2}\right)$ could play a major role in maintaining $\mathrm{NO}_{x}$ concentrations over the ocean [Singh, 1987]. Also, lightning may play an important role in the $\mathrm{NO}_{x}$ concentrations over the oceans. In the lower troposphere, $\mathrm{NO}_{\boldsymbol{x}}$ released from lightning is rapidly converted into nitrogen reservoir species, such as $\mathrm{HNO}_{3}$ and PAN. However. some of those reservoir species, especially PAN, can reproduce $\mathrm{NO}_{x}$ through thermal decomposition when the temperature is high. Transport of PAN and regeneration of $\mathrm{NO}_{x}$ can affect the atmospheric photochemistry even in lightning-free regions.

In this paper, we employ a global chemical/transport model, Model for Ozone And Related Chemical Tracers, version 1
(MOZART), to evaluate the effects of lightning on $\mathrm{NO}_{x}$ and especially on their reservoir species $\left(\mathrm{HNO}_{3}, \mathrm{PAN}, \mathrm{HNO}_{4}\right.$, and $\mathrm{N}_{2} \mathrm{O}_{5}$ ). The relative enhancements of, and the interactions among, the reactive nitrogen and nitrogen reservoir species due to lightning are discussed. The enhancement of $\mathrm{NO}_{x}$ in lightning-free regions due to the long-range transport of the nitrogen reservoir species is also investigated.

\section{Method and Results}

\subsection{Model Description}

The numerical model used in the present study is a global three-dimensional chemical/transport model

(MOZART) 
developed at the National Center for Atmospheric Research (NCAR) [Brasseur et al., 1998]. The model is a comprehensive tropospheric chemical/transport model, calculating the global distribution of 56 gas-phase chemical species. Version 1 of the model used here is configured with a T42 $\left(2.8^{\circ} \times 2.8^{\circ}\right)$ horizontal resolution and 25 hybrid vertical levels ranging from the surface to 4 mbar. There are four levels in the boundary layer ranging from the surface to 786 mbar. Meteorological information (i.e., winds, temperature. etc.) is provided by the NCAR Community Climate Model (CCM2) every 3 hours on the basis of precalculated results (off-line). The cloud water content and precipitation flux are generated from an early version of the prognostıc cloud parameterization described by Rasch and Kristjansson [1998]. In the present study, aqueous-phase chemistry in the clouds is not taken into account. However. both in-cloud and below-cloud scavenging in precipitation clouds are considered in this calculation. The rate of scavenging is a function of rainwater tendency and of the effective Henry's law constants. The model tume step for chemustry and transport is $20 \mathrm{~min}$. Chemical species are transported by advective [Rasch and Williamson. 1991], diffusive [Holtslag and Boville, 1993], and convective [Hack, 1994] processes. Details on the treatment of the gas-phase chernical mechanisms and transport processes are provided by Brasseur et al. [1998].

The global lightning emission is based upon the parameterization method developed by Price et al. [1997]. In their study, they present the global and seasonal distributions of lightning-produced $\mathrm{NO}_{\mathrm{r}}$ based on the observed distribution of electrical storms and the physical properties of lightning strokes. In the MOZART model the lightning emission is determined using the parameterization based on model-calculated convective cloud heights. Different assumptions have been made regarding the vertical distribution of the $\mathrm{NO}_{x}$ production within the clouds. In this study, we assume for simplicity that the $\mathrm{NO}_{x}$ emission (expressed in mass per unit volume) is distributed uniformly with height below the top of convective clouds and covers the entire grid-cell in which such clouds are present. The total global annual emission of nitrogen oxides is chosen to be $7 \mathrm{Tg} \mathrm{N} / \mathrm{yr}$ in the present study. The global horizontal distribution of lightning emissions calculated by MOZART is shown in Figure 1. In general, lightning actıvity depends on the incoming solar radiation and on the geographical distribution of land/ocean surfaces. In MOZART the distribution of lightning is determined by the location and height of convective clouds in CCM2, and therefore observed lightning distributions are not necessarily reproduced. The most intensive lightning activity occurs over land where the surface heating is maximal. Hence the seasonal variation of lightning activity is significant. In June, intensive lightning occurs at low latitudes in the northern hemisphere, while in December the lightning activity occurs primanly at low latitudes in the southern hemisphere. Marine convection, although occurring throughout the year, yields little lightning over the central Atlantic and Pacific [Nesbitt et al., 2000].

In order to calculate the effect of lightning on nitrogen species, a model simulation made without any lightning emissions is compared to the standard simulation. Figure 2 shows a comparison of the $\mathrm{NO}$, concentrations between the model calculations with and without the lightning source and observations made during the several aircraft field campaigns. The sites of the observations are indicated in Figure 3 and Table 1 and are further described by Emmons et al. [2000]. These selected sites represent different levels of lightning activity. Sites 1 and 2 are located in the Pacific, and represent regions of low lightning activity. Sites 3 and 4 are located between two large lightning regions (Africa and South America). Sites 5 and 6 are located on the east coast of Asia where lightning often occurs. Sites 7 to 10 are located in regions of high lightning activity (Africa and South Amenca). Figure 2 shows the significant contribution lightning makes to the $\mathrm{NO}_{1}$ distribution in the large difference between the model simulations with and without lightning. Over land and coastal areas (i.e., locations 5 to 10 in East Asia, Africa, and South America), the inclusion of the lightning $\mathrm{NO}_{x}$ source yields simulated profiles in much better agreement with the observed values. Those results also support our use of $7 \mathrm{Tg} \mathrm{N} / \mathrm{yr}$ lightning$\mathrm{NO}_{\mathrm{r}}$ production rate. Over the Pacific Ocean (i.e., locations 1 and 2) the simulated $\mathrm{NO}_{\mathrm{r}}$ excluding the lightning source shows a small difference from the observation and from the standard model results, suggesting that the influence of $\mathrm{NO}_{x}$ from lightning is quite small in this remote region. However. over the Atlantic Ocean (sites 3 and 4 ) the calculated $\mathrm{NO}_{x}$ profiles are improved compared to the observations when the lightning $\mathrm{NO}_{r}$ source is taken into account. Since lightning activity occurs primarily over continental areas, this implies possible transport of the nitrogen species derived from lightning-generated $\mathrm{NO}_{\mathrm{r}}$. This question will be addressed later. There is also a suggestion that there is a larger source of $\mathrm{NO}_{r}$ in the upper troposphere than would be expected from a uniform vertical distribution of lightning- $\mathrm{NO}_{x}$ production in the cloud [Pickering et al., 1998]. A sensitivity study in which vertical distribution of the $\mathrm{NO}_{x}$ production within the clouds is distributed in the top four levels of clouds is made in the calculation. The results show a maximum of $900 \%$ increase in $\mathrm{NO}_{r}$ concentrations (not shown) in the upper troposphere contrasted to $600 \%$ increase with uniformed vertical distribution of lightnıng- $\mathrm{NO}_{\mathrm{r}}$ production in the cloud, indicating that lightning $\mathrm{NO}_{r}$ production directly emitted in the upper troposphere play a significant role in controlling $\mathrm{NO}_{x}$ concentrations in this region.

\subsection{Changes in the Nitrogen Species Caused by Lightning}

Figure $4 \mathrm{a}$ shows the calculated zonally averaged changes in the relevant nitrogen species concentration due to lightning, including $\mathrm{NO}_{\mathrm{r}}\left(\mathrm{NO}+\mathrm{NO}_{2}\right), \mathrm{PAN}, \mathrm{HNO}_{3}, \mathrm{~N}_{2} \mathrm{O}_{5}, \mathrm{HNO}_{4}$, and $\mathrm{NO}_{y}\left(\mathrm{NO}_{x}+\right.$ $\mathrm{PAN}+\mathrm{HNO}_{3}+2 \mathrm{~N}_{2} \mathrm{O}_{5}+\mathrm{HNO}_{4}+\mathrm{NO}_{3}$ ) in June. The results indicate that the change in $\mathrm{NO}_{x}$ due to lightning represents less than $30 \%$ of the change in the total nitrogen concentrations. However, the change in the $\mathrm{NO}_{x}$ concentration can be large relative to ambient concentrations. Figure $4 \mathrm{a}$ shows that a maximum change of the $\mathrm{NO}_{x}$ mixing ratio (300 pptv) is located within a small latitude range (between $30^{\circ} \mathrm{N}$ and $40^{\circ} \mathrm{N}$ ) in the upper troposphere. In contrast, the increase in $\mathrm{NO}_{y}$ concentration is quite uniformly distributed in both horizontal and vertical directions. with an increase of over 200 pptv from $40^{\circ} \mathrm{N}$ to $40^{\circ} \mathrm{S}$ and 2 to $15 \mathrm{~km}$ in altitudes. This uniformity is due to the zonally averaged $\mathrm{NO}_{\mathrm{r}}$ emissions being fairly uniformed over $40^{\circ} \mathrm{S}-40^{\circ} \mathrm{N}$, and NOy having a long lifetime. The largest increase in the nitrogen species concentration from lightning occurs in the case of $\mathrm{HNO}_{3}$, with a maximum value of 300 pptv over a large vertical range at $15^{\circ}$ to $30^{\circ} \mathrm{N}$. The increase in PAN mixing ratio is also significant with a maximum value of 50 pptv. Figure 4 shows that the PAN enhancement is uniformly distributed in the middle and upper troposphere between $0^{\circ}$ and $50^{\circ} \mathrm{N}$ latitudes where intensive lightning occurs. The increases in $\mathrm{N}_{2} \mathrm{O}_{5}$ and $\mathrm{HNO}_{4}$ density are less significant than in the case of $\mathrm{NO}_{r}, \mathrm{HNO}_{3}$, and PAN. Figure 4b shows the calculated percentage increase of $\mathrm{NO}_{x}, \mathrm{NO}_{v}, \mathrm{PAN}$, 

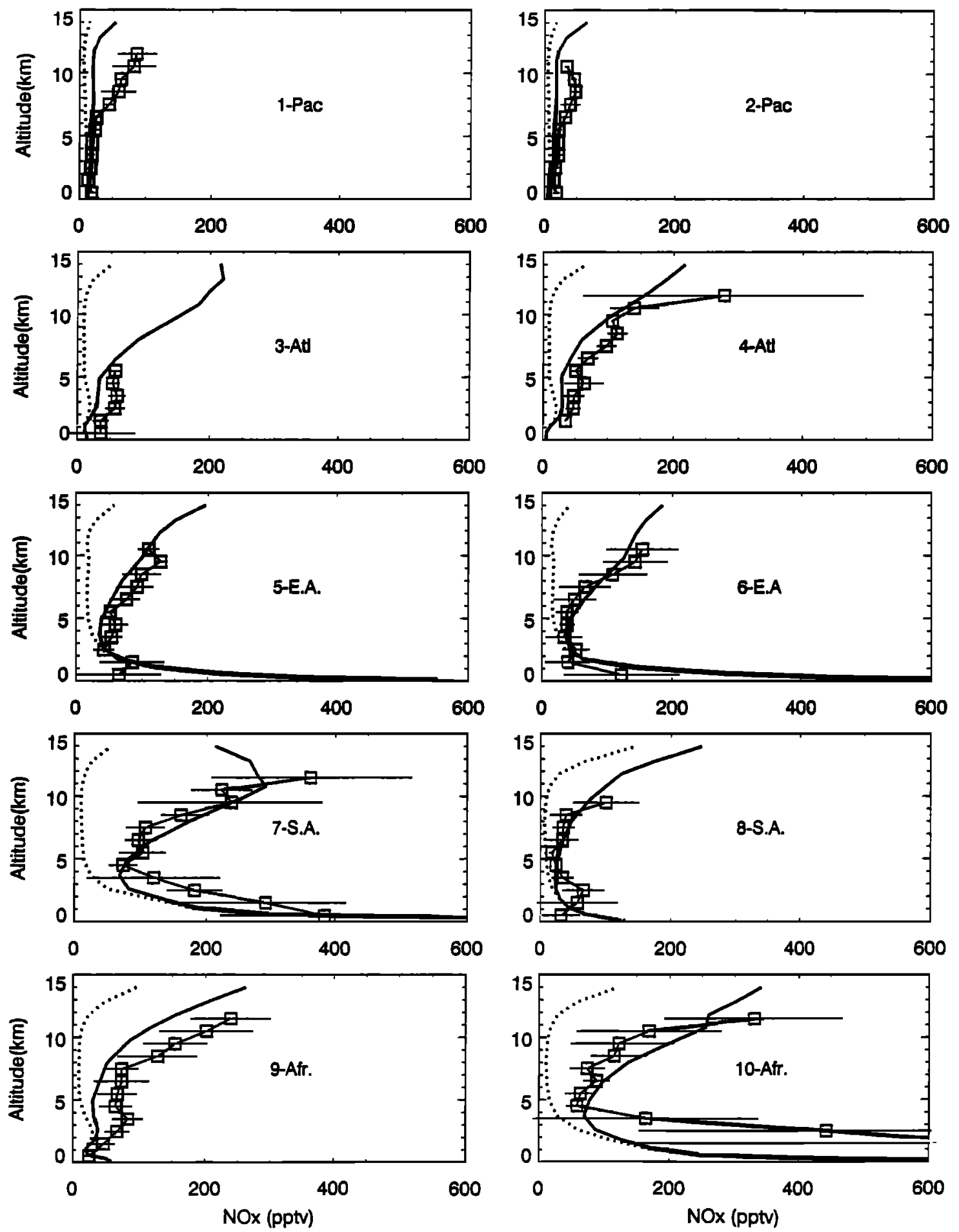

Figure 2. Comparison of $\mathrm{NO}_{\mathrm{r}}$ between model simulations with (solid line) and without lightning (dotted line) and observations (squares) in 10 different locations: 1 and 2, Pacific Ocean; 3 and 4, Atlantic Ocean; 5 and 6, East Asia; 7 and 8, Africa; 9 and 10, South America. The locations of the observations are shown in Figure 3.

$\mathrm{HNO}_{3}, \mathrm{~N}_{2} \mathrm{O}_{5}$, and $\mathrm{HNO}_{4}$ due to lightning. It shows that in the middle and upper troposphere of the tropics, $\mathrm{NO}_{x}$ and $\mathrm{NO}_{y}$ concentrations increase as much as a few hundred percent, indicating that lighting emission of $\mathrm{NO}_{x}$ is a major source of $\mathrm{NO}_{x}$ and $\mathrm{NO}_{3}$ in this region. We also note that although the percentage increase in $\mathrm{N}_{2} \mathrm{O}_{5}$ is very large (greater than $1000 \%$ ), the absolute change of $\mathrm{N}_{2} \mathrm{O}_{5}$ is very small (less than a few pptv. see Figure 4a).

Figure 5 shows the calculated zonally and vertically averaged latitudinal changes in the distributions of $\mathrm{NO}_{y}, \mathrm{NO}_{x}, \mathrm{HNO}_{3}$, and
PAN mixing ratios in June, along with the integrated lightning NO emissions. The enhanced $\mathrm{NO}_{x}$ concentrations are correlated with the lightning emission, but $\mathrm{NO}_{x}$ is also enhanced at latitudes outside the regions of the lightning emissions. This feature will be discussed in more detal in the following section. The changes in $\mathrm{NO}_{v}$ concentrations, however, are broadly distributed over a wide latitude range because of the long chemical lifetime (greater than 20 days) involved. The changes in the latitudinal gradient of $\mathrm{HNO}_{3}$ and PAN are very similar to that of $\mathrm{NO}_{y}$, but the $\mathrm{HNO}_{3}$ 


\section{Annual Mean Lightning and Observation Sites}
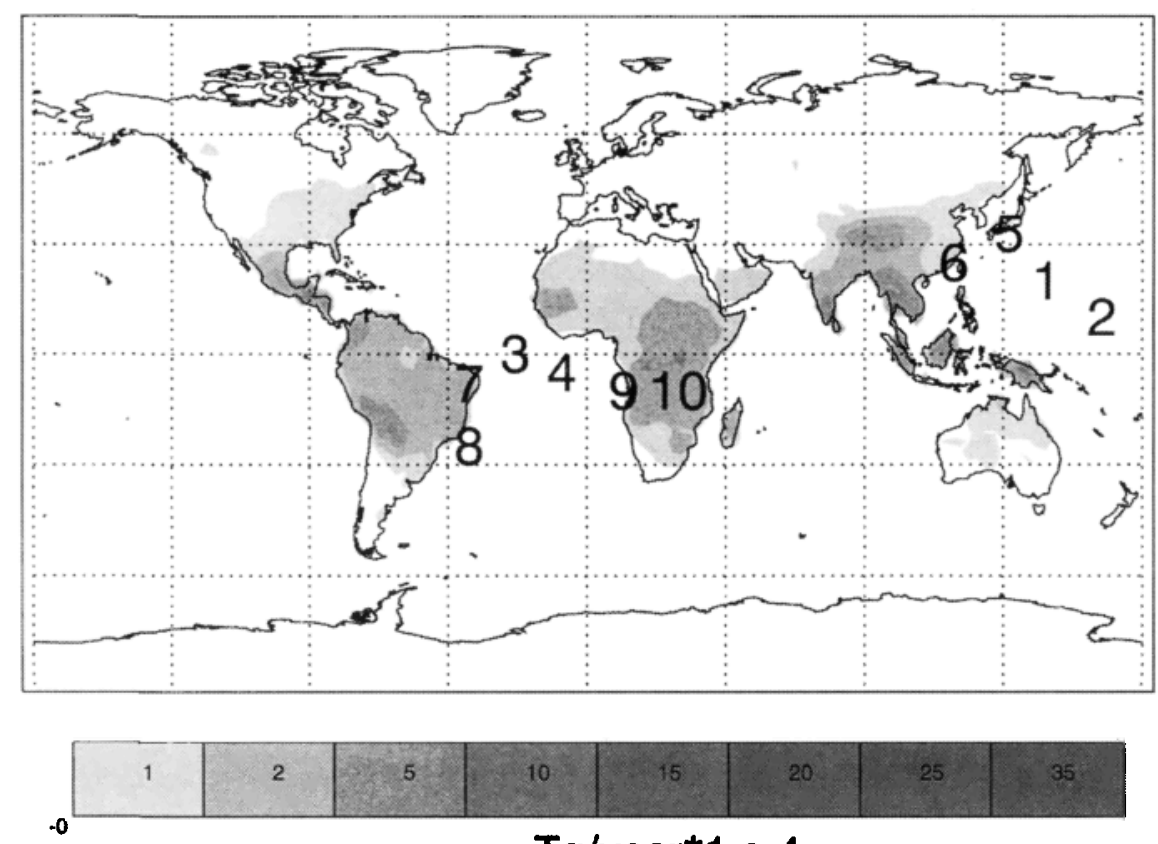

Tg/year*1.e-4

Figure 3. The annually averaged horizontal distribution of lightning $\mathrm{NO}_{\mathrm{r}}$ emission and the locations of observation sites (indicated by numbers used for the comparison of $\mathrm{NO}_{\mathrm{r}}$ between model simulations and observations.

concentration increase is about 7 times larger than the increase in the PAN density. Note that the lightning activity in June is very intensive between the equator and $50^{\circ} \mathrm{N}$, as shown in Figure 5 .

To more closely examine the correlation between lightning emission and the enhancements (in percentages of total nitrogen changes due to lightning) in $\mathrm{NO}_{x}, \mathrm{HNO}_{3}$, and PAN, we calculate the vertical profiles of the changes of $\mathrm{NO}_{x}, \mathrm{PAN}$, and $\mathrm{HNO}_{3}$ averaged over three latitudinal bands in June, that is, between $10^{\circ} \mathrm{S}$ and $90^{\circ} \mathrm{S}$ (the low lighting activity zone in the winter), $10^{\circ} \mathrm{S}$ and $60^{\circ} \mathrm{N}$ (the high lightning activity zone), and $60^{\circ} \mathrm{N}$ and $90^{\circ} \mathrm{N}$ (the low lightning activity zone in the summer) as shown in Figure 6. In the region between $10^{\circ} \mathrm{S}$ and $90^{\circ} \mathrm{S}$, most of the enhancement of nitrogen due to lightning is in the form of $\mathrm{HNO}_{3}$ (about 70 to $80 \%$ ). The increase in PAN accounts for 20 to $30 \%$ of the $\mathrm{NO}_{y}$ enhancement below $10 \mathrm{~km}$. The $\mathrm{NO}_{x}$ enhancement is very small below $5 \mathrm{~km}$ and gradually increases to $15 \%$ above 10 $\mathrm{km}$. In the latitudinal band between $60^{\circ} \mathrm{N}$ and $90^{\circ} \mathrm{N}$, the situation is very similar to that between $10^{\circ} \mathrm{S}$ and $90^{\circ} \mathrm{S}$. However, in the region between $10^{\circ} \mathrm{S}$ and $60^{\circ} \mathrm{N}$ where intensive lightning activity occurs, the enhancement of $\mathrm{NO}_{x}$ is larger in the upper troposphere ( 30 to $40 \%$ increase of the nitrogen concentration). In the lower troposphere the $\mathrm{NO}_{\mathrm{r}}$ increase is less than $10 \%$, and most nitrogen enhancement is in the form of $\mathrm{HNO}_{3}$, which accounts for $80 \%$ increase of the nitrogen species.

To understand the relative enhancement of the nitrogen species due to lightning. we calculate the timescales for chemical production and destruction of $\mathrm{HNO}_{3}$ and PAN in June. The results are shown in Figure 7. The time constant to form $\mathrm{HNO}_{3}$ and $\mathrm{PAN}$ is less than 1 day in the tropical lower troposphere because high $\mathrm{OH}$ concentrations are located in this region. The formation of $\mathrm{HNO}_{3}$ occurs through the direct reaction of $\mathrm{NO}_{2}$ with $\mathrm{OH}$, and it is expressed by

Table 1. Observations Shown in Figure 2 With Locations Indicated in Figure 3

\begin{tabular}{lllll}
\hline Location & Campaign & \multicolumn{1}{c}{ Date } & \multicolumn{1}{c}{ Region } & \multicolumn{1}{c}{$\begin{array}{c}\text { Latitude, } \\
\text { Longitude, deg }\end{array}$} \\
\hline 1 & PEM-West A & Sept. 16 to Oct. 21, 1991 & Philippine Sea & 5-20N, 135-150E \\
2 & PEM-West A & Sept. 16 to Oct. 21, 1991 & Pacific_Tropics_W & 5S-15N, 155-165E \\
3 & CITE 3 & Aug. 22 to Sept. 29, 1989 & Natal & 5S-5N, 325-335E \\
4 & TRACE-A & Sept. 21 to Oct. 26, 1992 & Atlantic_S & 20S-0, 340-350E \\
5 & PEM-West A & Sept. 16 to Oct. 21, 1991 & Japan_Coast_E & 25-40N, 135-150E \\
6 & PEM-West A & Sept. 16 to Oct. 21, 1991 & China_Coast_E & 20-30N, 115-130E \\
7 & TRACE-A & Sept. 21 to Oct. 26, 1992 & Brazil_E & 15-5S, 310-320E \\
8 & TRACE-A & Sept. 21 to Oct. 26. 1992 & Brazil_Coast & 35-25S, 310-320E \\
9 & TRACE-A & Sept. 21 to Oct. 26, 1992 & Africa_Coast_W & 25-5S, 0-10E \\
10 & TRACE-A & Sept. 21 to Oct. 26, 1992 & Africa_S & 25-5S, 15-35E \\
\hline
\end{tabular}


Changes due to lightning (\%)
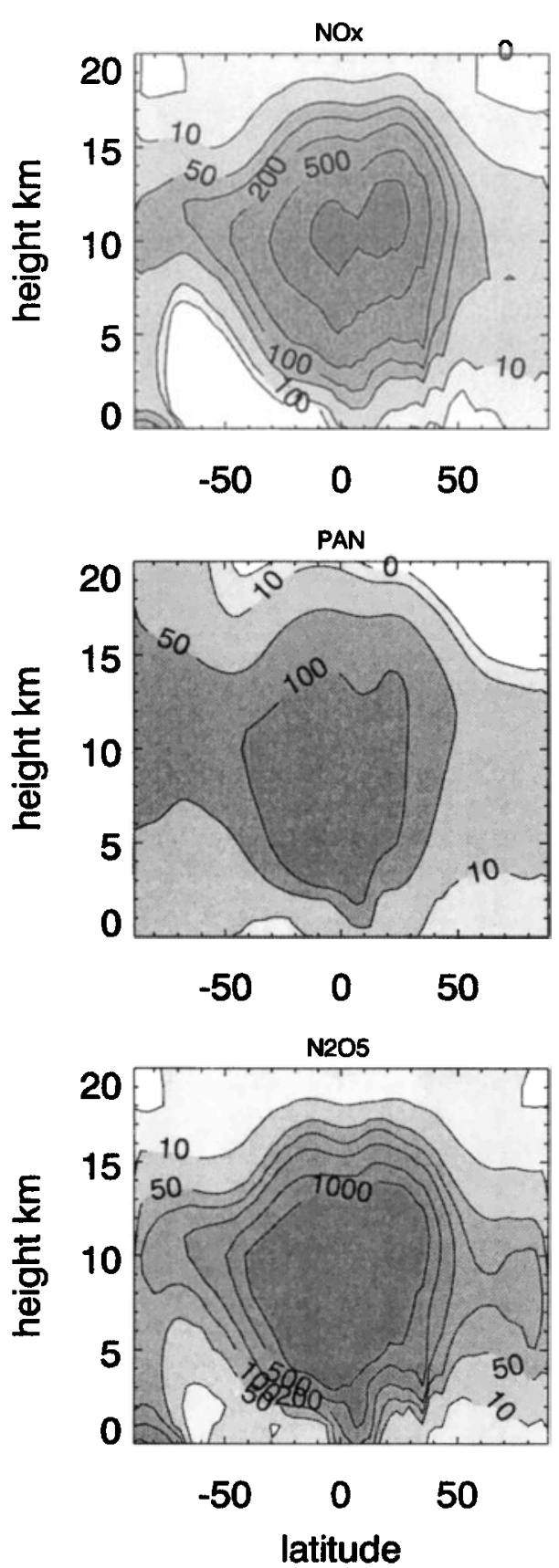

(Jun.)
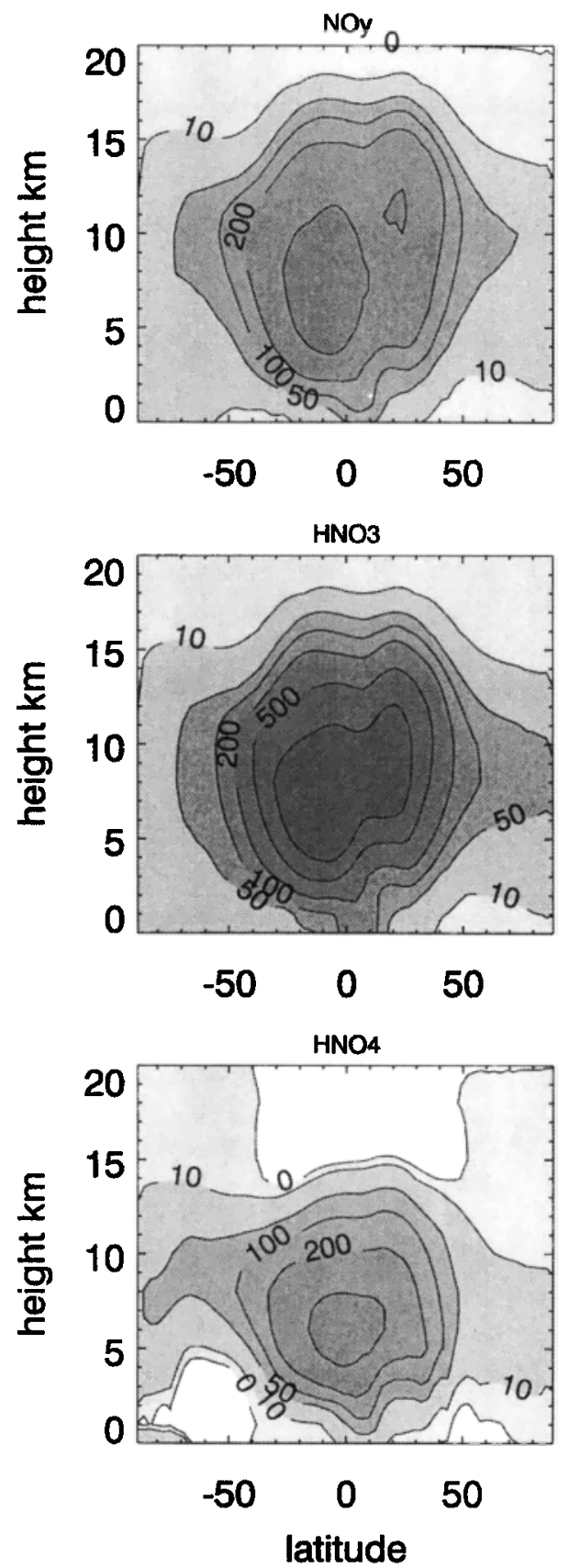

Figure 4a. Zonally averaged changes of nitrogen species from lightning, including $\mathrm{NO}_{x}\left(\mathrm{NO}_{+} \mathrm{NO}_{2}\right), \mathrm{PAN}, \mathrm{HNO}_{3}$, $\mathrm{N}_{2} \mathrm{O}_{5}, \mathrm{HNO}_{4}$, and $\mathrm{NO},\left(\mathrm{NO}_{\mathrm{r}}+\mathrm{PAN}+\mathrm{HNO}_{3}+2 \mathrm{~N}_{2} \mathrm{O}_{5}+\mathrm{HNO}_{4}+\mathrm{NO}_{3}\right)$ in June.

$$
\mathrm{OH}+\mathrm{NO}_{2} \rightarrow \mathrm{HNO}_{3}
$$

For PAN, however. the situation is somewhat different. The formation of PAN is through a chemical chain reaction, initiated by the oxidation of hydrocarbons, for example, propene $\left(\mathrm{C}_{3} \mathrm{H}_{6}\right)$

$$
\begin{aligned}
& \mathrm{C}_{3} \mathrm{H}_{6}+\mathrm{O}_{3} \rightarrow \mathrm{CH}_{3} \mathrm{CHO}+\text { products } \\
& \mathrm{C}_{3} \mathrm{H}_{6}+\mathrm{OH}+\mathrm{O}_{2} \rightarrow \mathrm{C}_{3} \mathrm{H}_{6} \mathrm{OHO}_{2} \\
& \mathrm{C}_{3} \mathrm{H}_{6} \mathrm{OHO} \mathrm{O}_{2}+\mathrm{NO} \rightarrow \mathrm{CH}_{3} \mathrm{CHO}^{2} \text { products } \\
& \mathrm{CH}_{3} \mathrm{CHO}+\mathrm{OH}+\mathrm{O}_{2} \rightarrow \mathrm{CH}_{3} \mathrm{CO}_{3}+\mathrm{H}_{2} \mathrm{O} \\
& \mathrm{CH}_{3} \mathrm{CHO}+\mathrm{NO}_{3} \rightarrow \mathrm{CH}_{3} \mathrm{CO}_{3}+\mathrm{HNO}_{3} \\
& \mathrm{CH}_{3} \mathrm{CO}_{3}+\mathrm{NO}_{2}+\mathrm{M} \rightarrow \mathrm{PAN}+\mathrm{M} .
\end{aligned}
$$

(6) and $\mathrm{HNO}_{3}$ will primarily be removed from the atmosphere by wet lifetume of approximately 20 , 30 days in the tropics, and even larger at high lattudes during the winter. Because the photochemical rate of destruction of $\mathrm{HNO}_{3}$ is much siower than its production rate, especially in the tropics, the cycling of $\mathrm{NO}_{x}$ through the chemucal destruction of $\mathrm{HNO}_{3}$ is slow, that is,

$$
\begin{aligned}
& \mathrm{HNO}_{3}+\mathrm{hv} \rightarrow \mathrm{OH}+\mathrm{NO}_{2} \\
& \mathrm{HNO}_{3}+\mathrm{OH} \rightarrow \mathrm{NO}_{3}+\mathrm{H}_{2} \mathrm{O}
\end{aligned}
$$

$$
\text { (7) and dry deposition, representing a major role for the sink of } \mathrm{NO}_{x}
$$




\section{Changes due to lightning (pptv)}

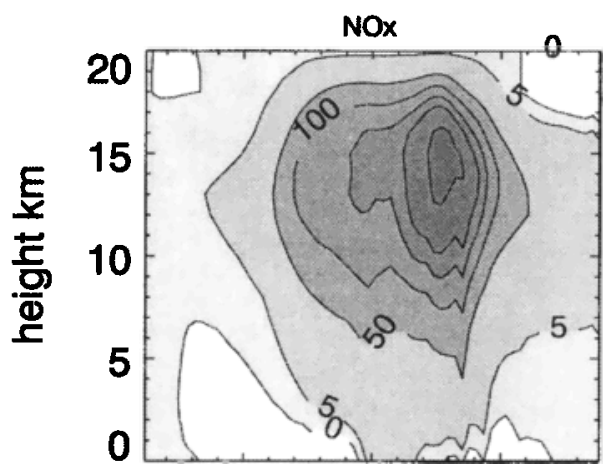

$\begin{array}{lll}-50 & 0 & 50\end{array}$

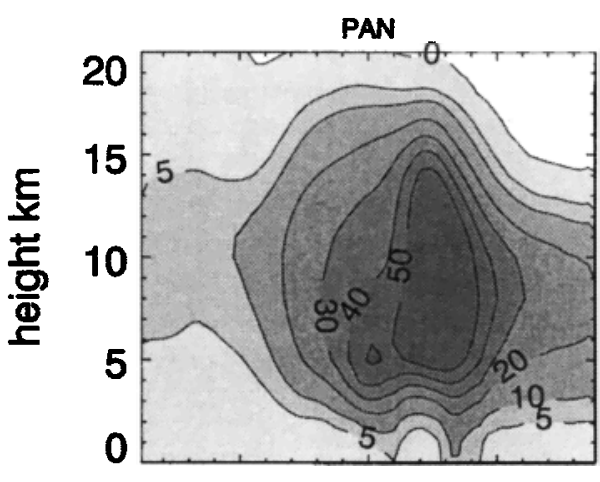

$\begin{array}{lll}-50 & 0 & 50\end{array}$

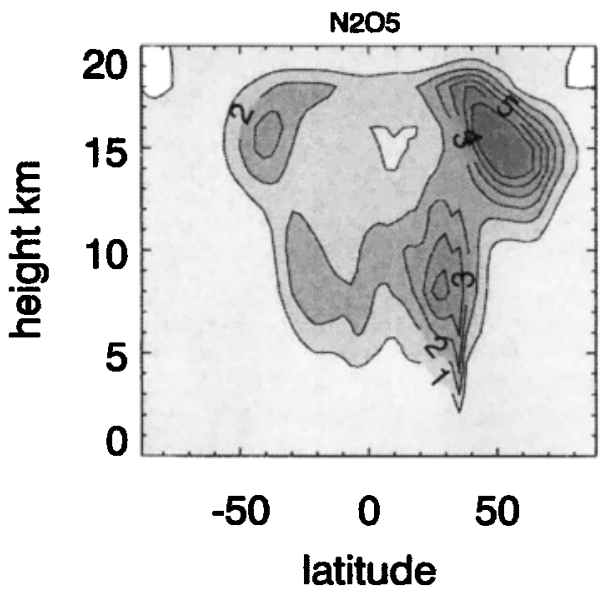

(Jun.)

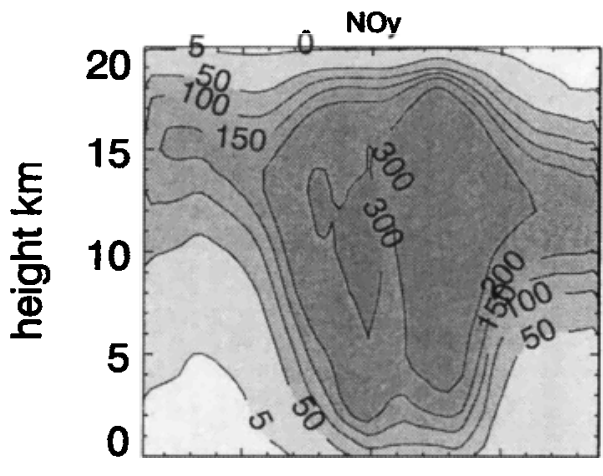

$\begin{array}{lll}-50 & 0 & 50\end{array}$
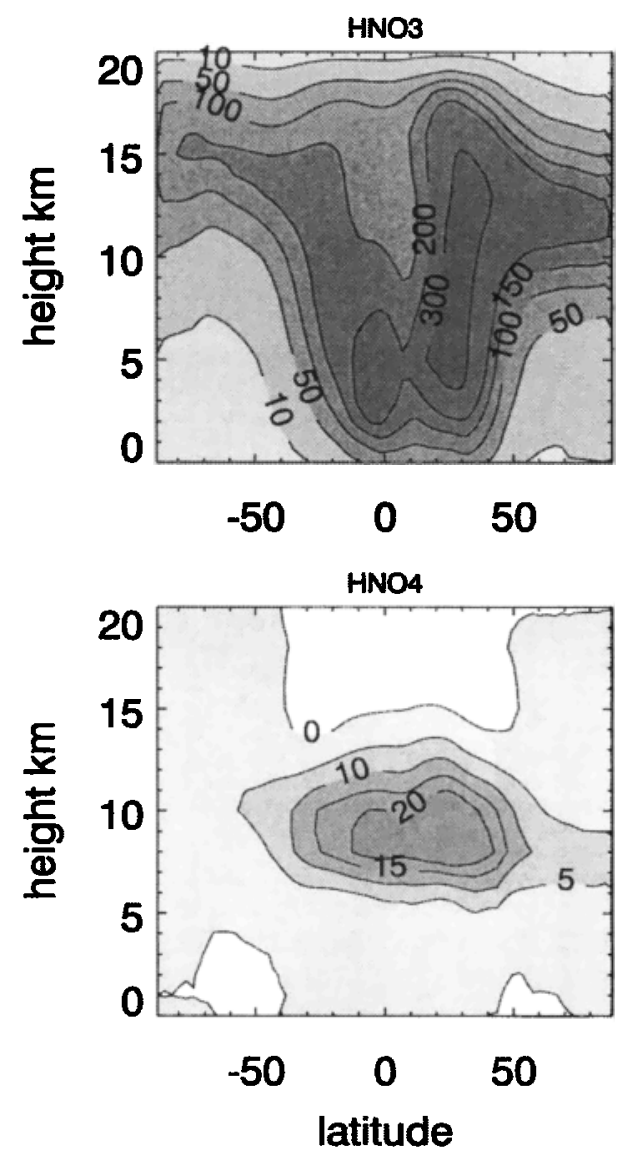

Figure 4b. Same as Figure 4a, except changes in percent.

[Brasseur et al., 1998]. Furthermore, the chemical lifetime of $\mathrm{HNO}_{3}$ is often longer than the transport time constant along longitude (approximate 1-2 weeks). As a result, the enhancement in $\mathrm{HNO}_{3}$ from lightning is almost uniform with longitude which will be discussed further below. The conversion of $\mathrm{NO}_{x}$ to $\mathrm{HNO}_{3}$ has several possible consequences. First, the enhancement in $\mathrm{NO}_{x}$ due to lightning is not significant below $5 \mathrm{~km}$, as depicted in Figures 4 and 6. Second, a significant enhancement of $\mathrm{NO}_{x}$ by lightning can occur in the upper troposphere, as shown by satellite measurements [Zhang et al., 2000]. Third, the slow destruction of $\mathrm{HNO}_{3}$ allows for its transport over long distances away from lightning source regions, resulting in a large scale enhancement in NO, over the globe as shown in Figures 4 and 5. Fourth, since the conversion of $\mathrm{HNO}_{3}$ to $\mathrm{NO}_{2}$ (reaction (8)) is slow, the enhancement of $\mathrm{HNO}_{3}$ in regions far from lighting activity will not produce a large increase in the $\mathrm{NO}_{x}$ concentrations.

In the lower atmosphere the destruction of PAN is mainly due to its thermal decomposition,

$$
\mathrm{PAN}+\mathrm{M} \rightarrow \mathrm{CH}_{3} \mathrm{CO}_{3}+\mathrm{NO}_{2}+\mathrm{M}
$$

which is rapid when temperature is high. As shown by Figure 7, the production of PAN is relatively fast in the tropical lower troposphere, with a time constant of about 1 day. The destruction rate of PAN is strongly dependent on altitude. In the lower troposphere the decomposition of PAN is very fast because of the 


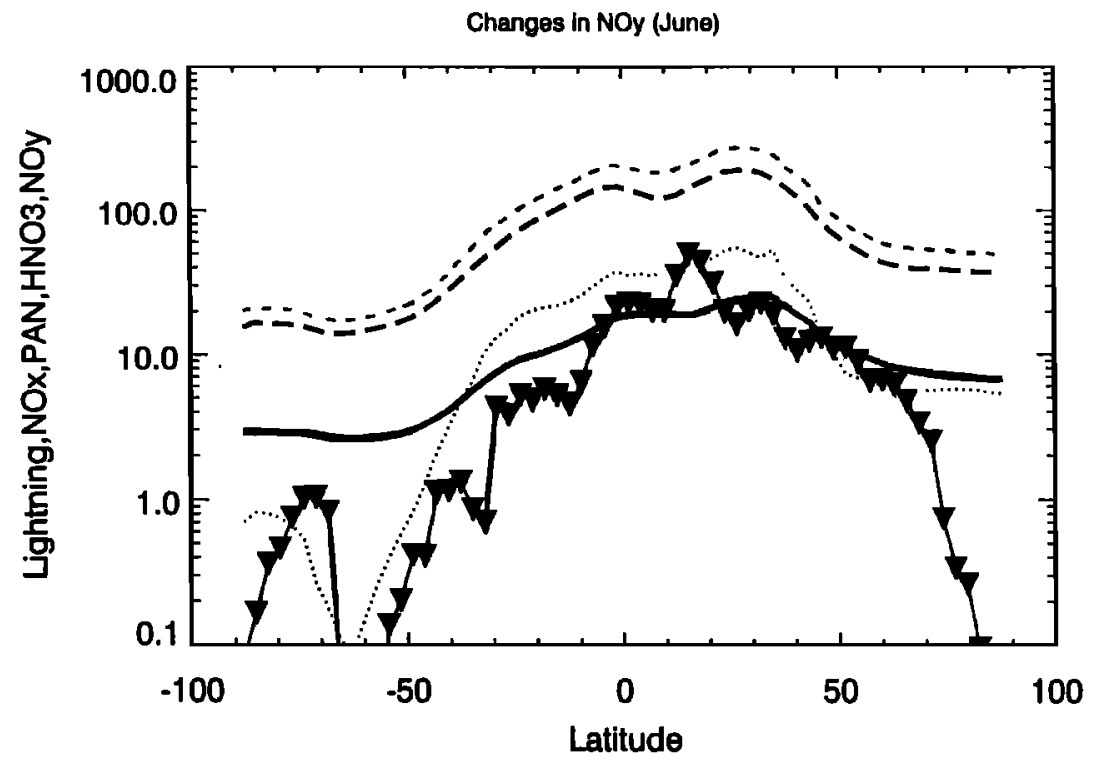

Figure 5. Calculated zonally and vertically averaged latitudinal changes (pptv) in the distributions of $\mathrm{NO}_{y}$ (shortdashed line), $\mathrm{NO}_{\mathrm{r}}$ (dotted line), $\mathrm{HNO}_{3}$ (long-dashed line), and PAN (solid line) in June. Also shown in this figure for comparison is the zonally averaged latitudinal lightning emssions $\left(10^{-4} \mathrm{Tg} / \mathrm{yr}\right)$ (triangles).

Changes due to Lightning (June)
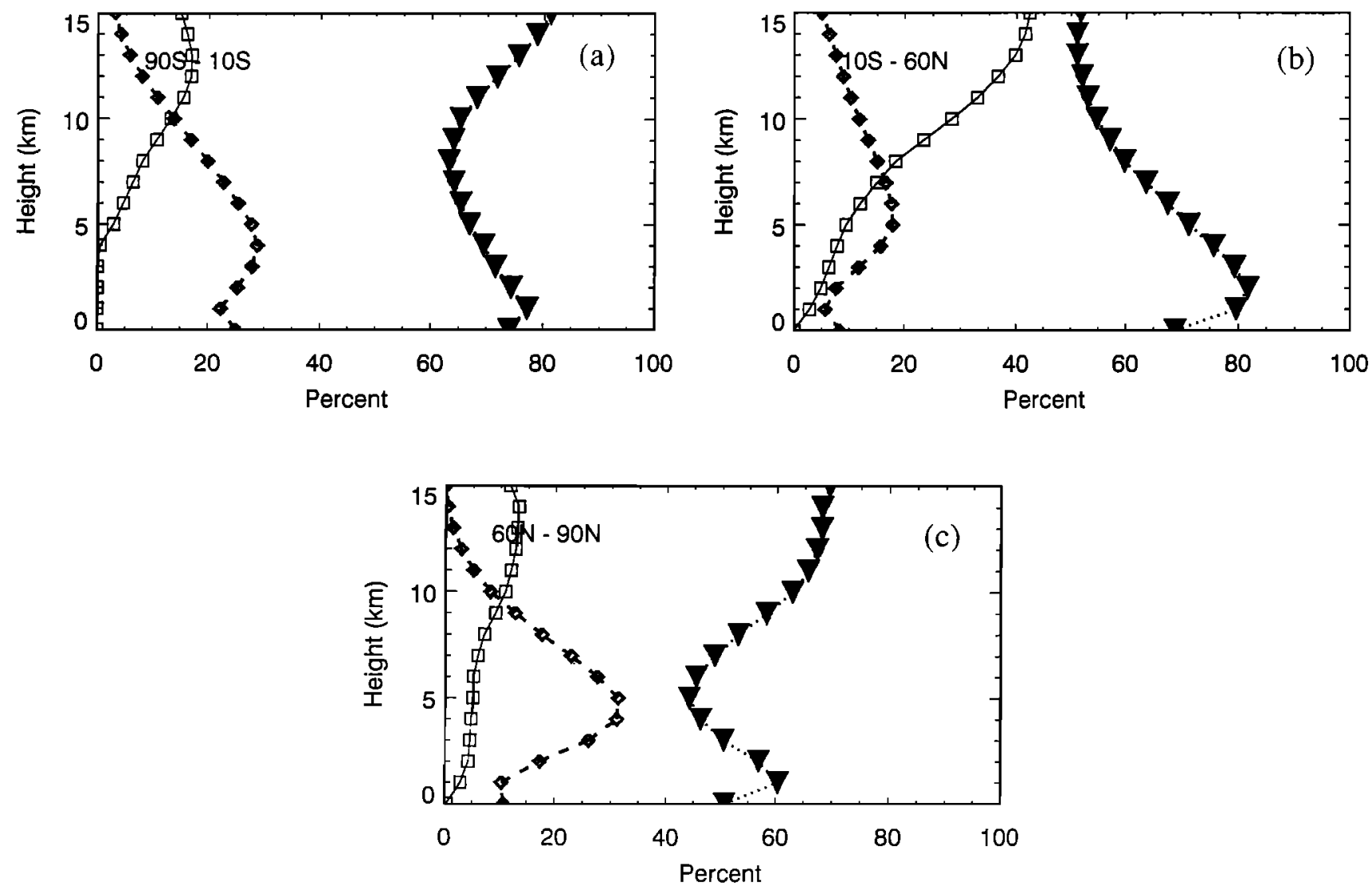

Figure 6. Averaged vertical profiles of the changes (in percentages of total nitrogen changes due to lightning) of $\mathrm{NO}_{x}$ (squares), PAN (diamonds), and $\mathrm{HNO}_{3}$ (triangles) in three latitudinal bands: (top) between $10^{\circ} \mathrm{S}$ and $90^{\circ} \mathrm{S}$, (middle) between $10^{\circ} \mathrm{S}$ and $60^{\circ} \mathrm{N}$, and (bottom) between $60^{\circ} \mathrm{N}$ and $90^{\circ} \mathrm{N}$. 


\section{0mb JUNE}

\section{Changes PAN (ppt)}
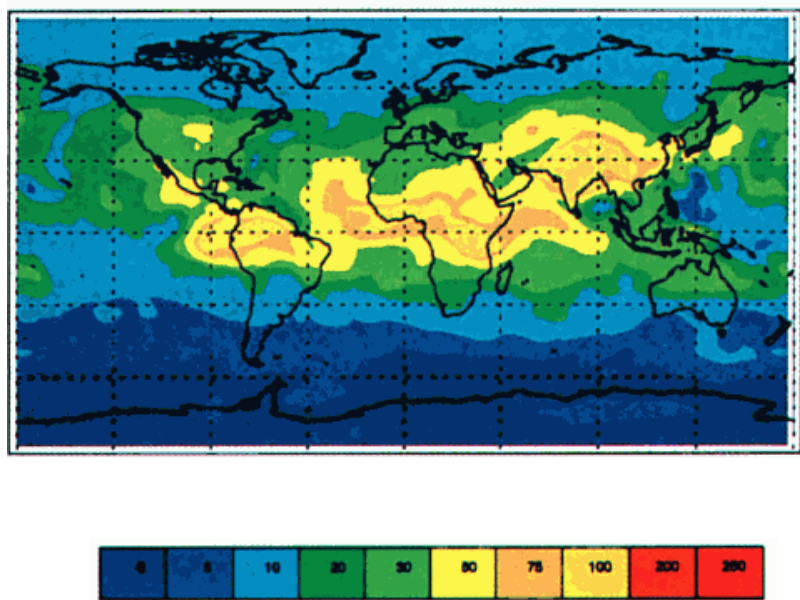

\section{Changes HNO3 (ppt)}
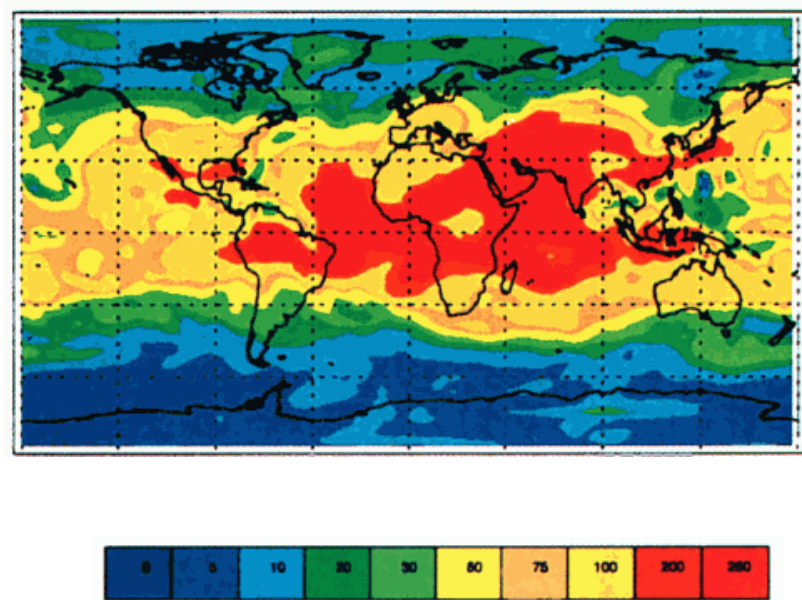

\section{Changes NOx (ppt)}

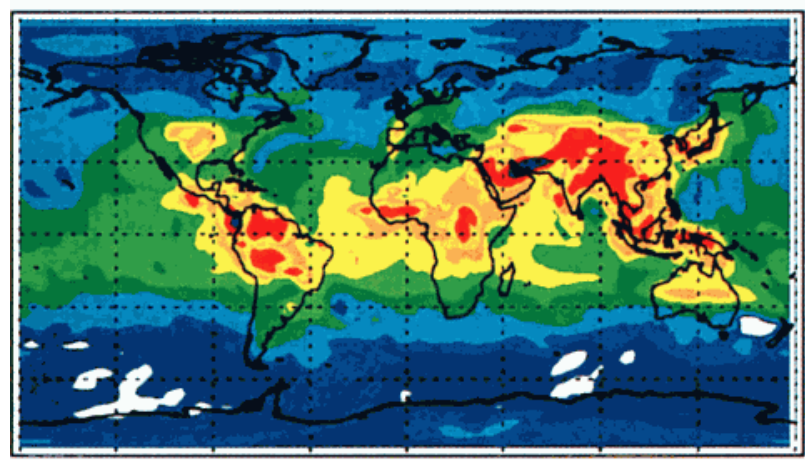

Recyc. of NOx from PAN (ppt/day)
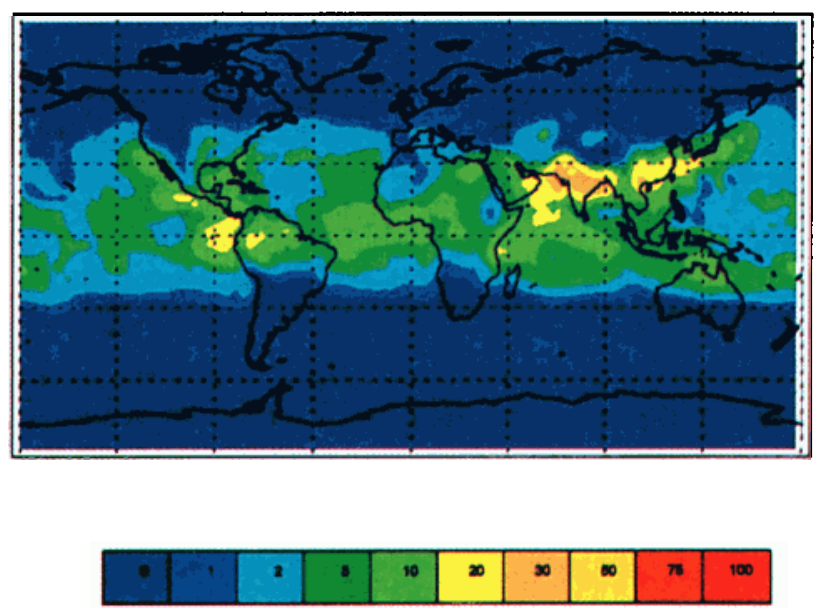

Recyc. of NOx from HNOS (ppt/day)
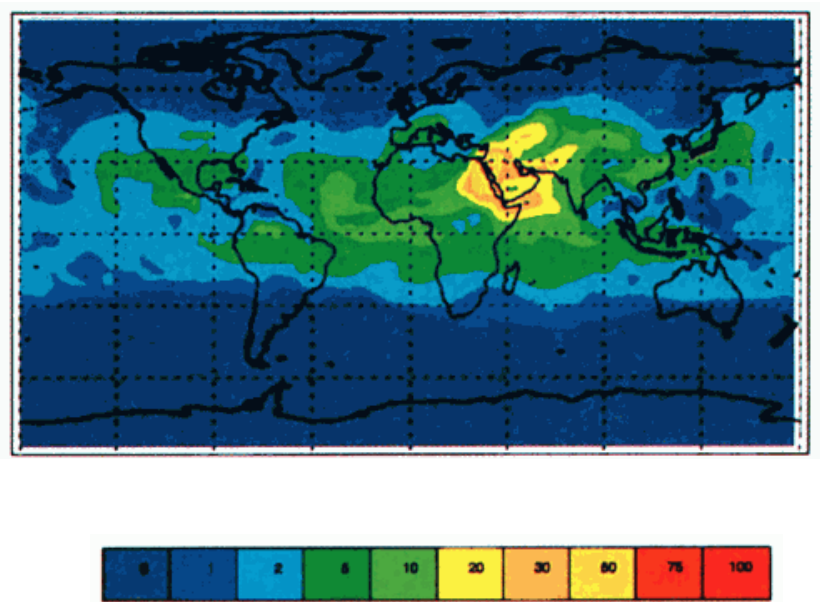

Recyc. of NOx (ppt)

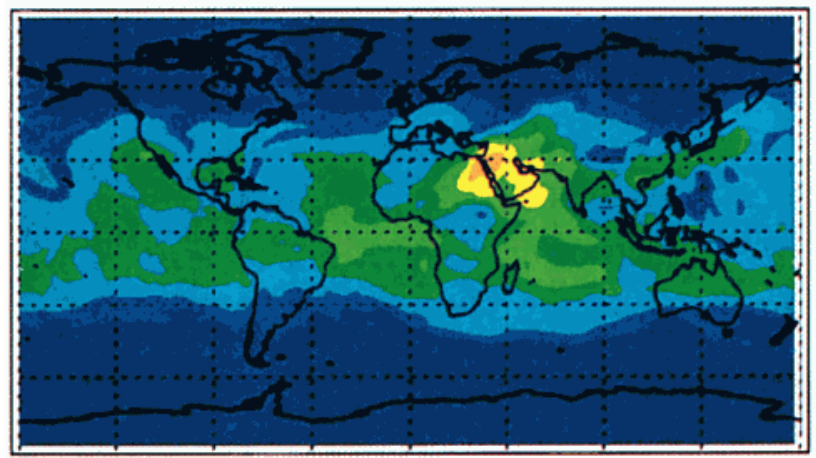

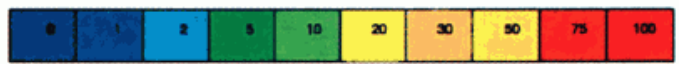

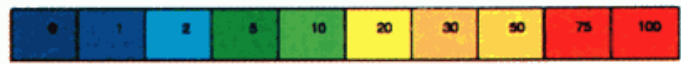

Plate 1. (left) Calculated lightning enhancements of $\mathrm{PAN}, \mathrm{HNO}_{3}$, and $\mathrm{NO}_{x}$ as well as (right) the rate of the recycling of $\mathrm{NO}_{x}$ from lightning-enhanced $\mathrm{PAN}$ and $\mathrm{HNO}_{3}$, and total $\mathrm{NO}_{x}$ recycled $\left(R \mathrm{NO}_{r}\right)$ at 500 mbar in June. 


\section{$300 \mathrm{mb}$ JUNE}

\section{Changes PAN (ppt)}
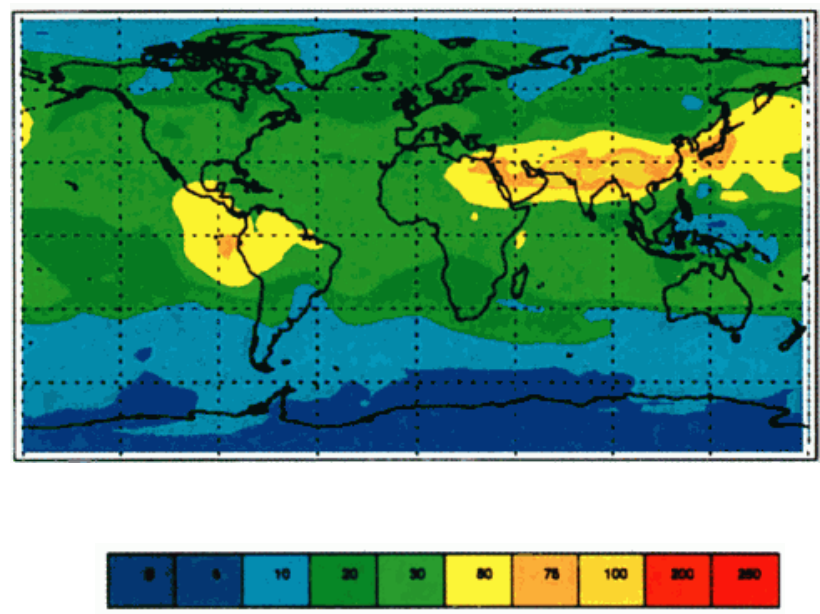

Changes HNOS (ppt)
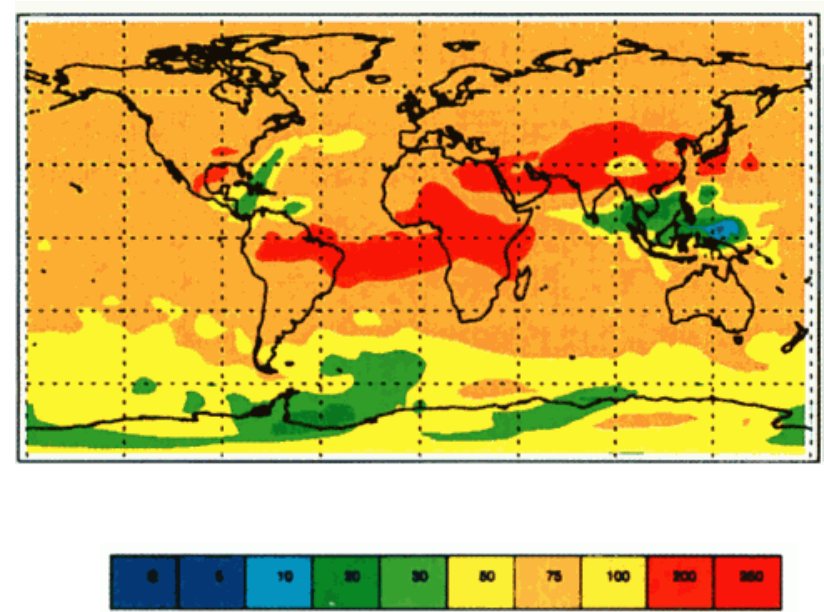

Changes NOx (ppt)

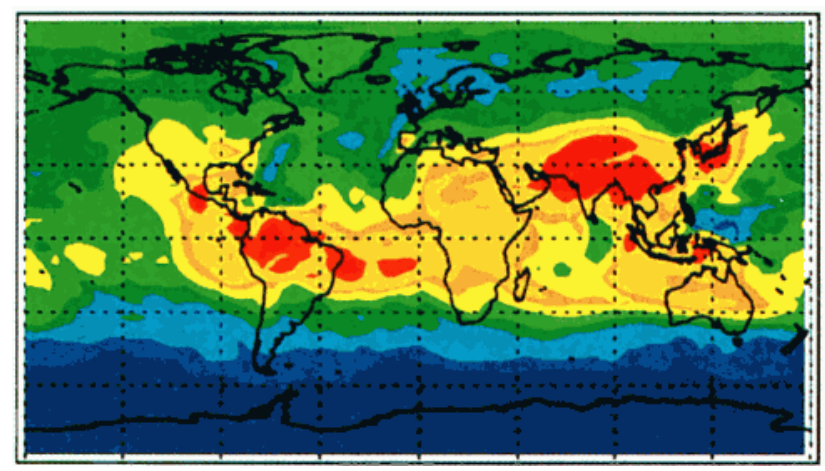

Recyc. of NOx trom PAN (ppt/day)
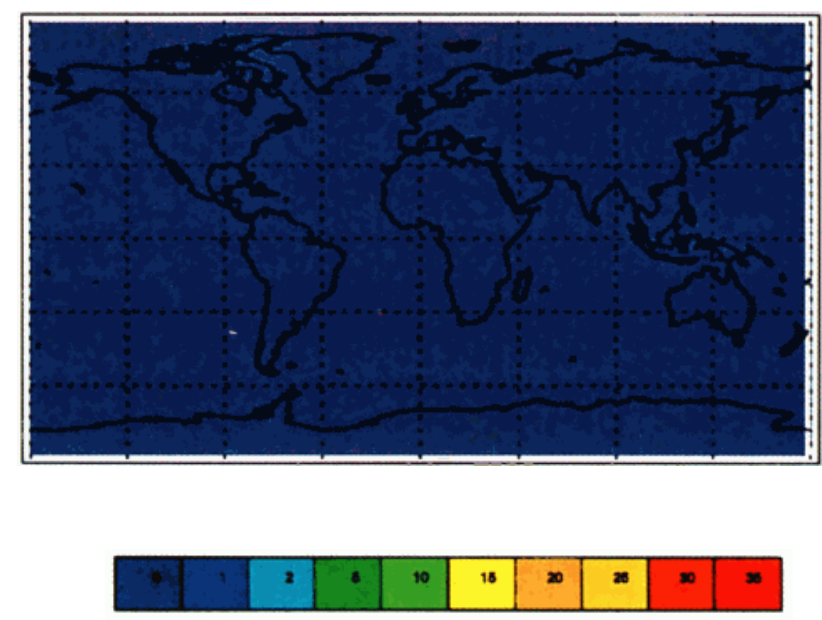

Recyc. of NOx from HNO3 (ppt/day)
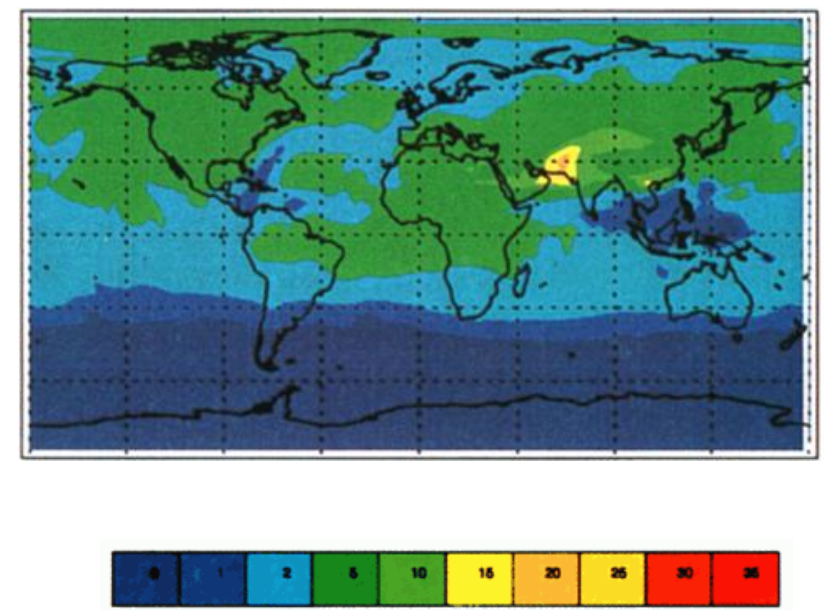

Recyc. of NOx (ppt)

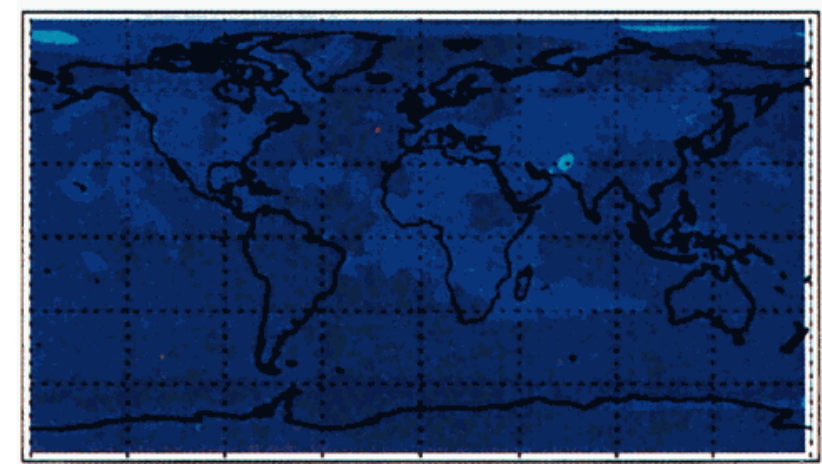

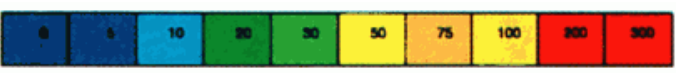

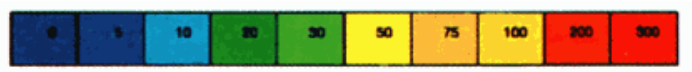

Plate 2. Same as Plate 1 except at $\mathbf{3 0 0}$ mbar. 


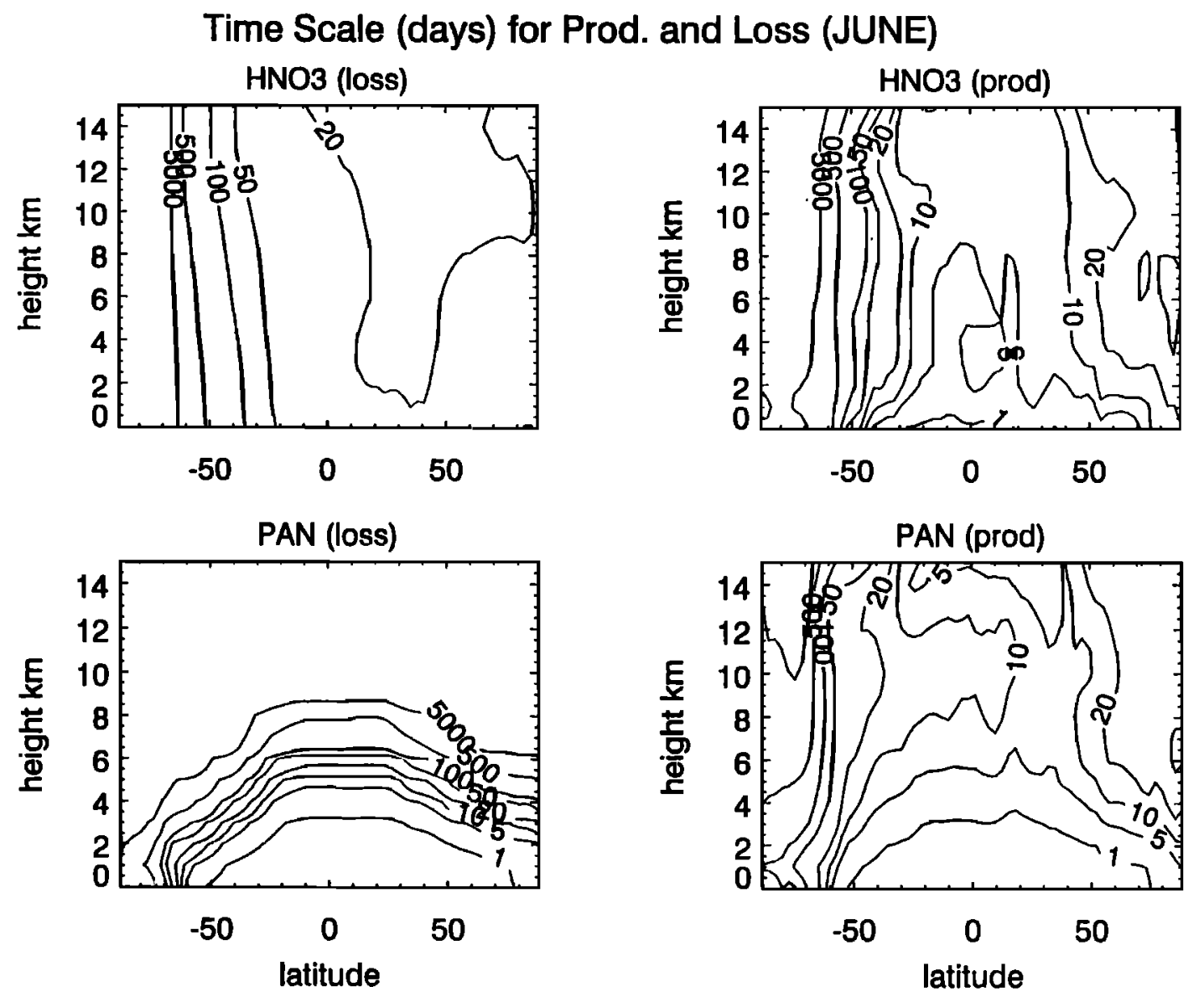

Figure 7. Timescales for chemical production and destruction of $\mathrm{HNO}_{3}$ and $\mathrm{PAN}$ in June.

warmer temperature in this region, corresponding to a chemical lifetime of less than 1 day. In the middle and upper troposphere the chemical lifetime of PAN is long, so that this compound is very stable above $5 \mathrm{~km}$. As a result, the longitudinal distribution of PAN is quite uniform in the upper troposphere.

\subsection{Recycling of $\mathrm{NO}_{x}$ From $\mathrm{HNO}_{3}$ and PAN}

The formation and destruction of nitrogen reservoirs such as PAN and $\mathrm{HNO}_{3}$ have important implications for the $\mathrm{NO}_{x}$ enhancement associated with lightning activities in the following ways. First, as indicated above, significant amounts of $\mathrm{NO}_{x}$ released by lightning are converted to these stable reservoirs (see Figure 4). Because of their slow destruction, $\mathrm{HNO}_{3}$ and $\mathrm{PAN}$ are transported over long distances away from lightning regions in the middle and upper troposphere. In the lower troposphere the fast decomposition of PAN regenerates $\mathrm{NO}_{\mathrm{r}}$. As a result, the enhancement of $\mathrm{NO}_{\mathrm{r}}$ from lightning is not only limited to the lightning source regions. To quantitatively analyze the recycling of $\mathrm{NO}_{1}$ from lightning, we calculate the following quantities;

$$
\begin{aligned}
& P_{1}\left(\mathrm{NO}_{\mathrm{r}}\right)=J_{2}\left[\Delta \mathrm{HNO}_{3}\right]+k_{3}[\mathrm{OH}]\left[\Delta \mathrm{HNO}_{3}\right] \\
& P_{2}\left(\mathrm{NO}_{x}\right)=k_{10}[\Delta \mathrm{PAN}] \\
& L\left(\mathrm{NO}_{\mathfrak{r}}\right)=k_{9}\left[\mathrm{CH}_{3} \mathrm{CO}_{3}\right]+k_{1}[\mathrm{OH}] \\
& R \mathrm{NO}_{x}=\left[P_{1}\left(\mathrm{NO}_{\mathrm{r}}\right)+P_{2}\left(\mathrm{NO}_{\mathrm{r}}\right)\right] / L\left(\mathrm{NO}_{x}\right),
\end{aligned}
$$

where $P_{1}\left(\mathrm{NO}_{r}\right)$ is the production rate of $\mathrm{NO}_{\mathrm{r}}$ from the lightningenhanced $\mathrm{HNO}_{3}\left(\Delta \mathrm{HNO}_{3}\right), P_{3}\left(\mathrm{NO}_{\tau}\right)$ is the corresponding quantity from the lightning-enhanced PAN ( $\triangle \mathrm{PAN}), L\left(\mathrm{NO}_{\mathrm{r}}\right.$ ) represents the chemical loss of $\mathrm{NO}_{x}$, and $R \mathrm{NO}_{1}$ is the $\mathrm{NO}_{\mathrm{r}}$ concentration due to the recycling of $\triangle \mathrm{HNO}_{3}$ and $\triangle \mathrm{PAN}$.

Plate 1 shows the enhancements of PAN( $\triangle \mathrm{PAN})$, $\mathrm{HNO}_{3}\left(\Delta \mathrm{HNO}_{3}\right)$, and $\mathrm{NO}_{\mathrm{r}}\left(\Delta \mathrm{NO}_{x}\right)$ at 500 mbar in June. With a chemical lifetime of approxımately 20 to 50 days for $\mathrm{HNO}_{3}$ and approximately 5 to 10 days for PAN at 500 mbar in the tropics (see Figure 7), the enhanced $\mathrm{HNO}_{3}$ and PAN concentrations from lightning are distributed uniformly in the tropıcs, in response to long-range transport of these slow reacting compounds. The enhancement of $\mathrm{NO}_{r}$ is located primarily in the regions where lightning acuvity is strong. However, significant $\mathrm{NO}_{x}$ enhancement ( 10 to $20 \mathrm{pptv}$ ) is found over the oceans in regions where lightnıng activity is very small (see Figure 1). The enhancements of $\mathrm{NO}_{\tau}$ over the tropical oceans can result from two processes: (1) The lightning-enhanced $\mathrm{NO}_{x}$ in the continents being transported over the oceans, and (2) $\mathrm{NO}_{r}$ being recycled from the lightning-enhanced PAN and $\mathrm{HNO}_{3}$. The rates of production rate of $\mathrm{NO}_{x}$ resulting from $\triangle \mathrm{PAN}$ and $\triangle \mathrm{HNO}_{3}$ as well as the concentrations increase of $\mathrm{NO}_{x}\left(R \mathrm{NO}_{\tau}\right)$, calculated by the model, are shown in Plate 1 (right panels). This indicates that the $\mathrm{NO}_{x}$ production from $\triangle$ PAN corresponds to approximately 2 to 20 pptv/d and from $\Delta \mathrm{HNO}_{3}$ to approximately 2 to $10 \mathrm{pptv} / \mathrm{d}$ over the oceans. The recycling of $\mathrm{NO}_{x}$ from both the lightning-enhanced $\mathrm{HNO}_{3}$ and PAN produces 10 to 20 pptv $\mathrm{NO}_{x}$ increases over the tropical oceans. A comparison of $R \mathrm{NO}_{x}$ with $\Delta \mathrm{NO}_{x}$ shows that the recycling of $\mathrm{NO}_{x}$ contributes approximately $50 \%$ of the lightning enhancement of $\mathrm{NO}_{x}$ over the oceans at 500 mbar. 
In the upper troposphere (300 mbar) the lifetime of $\mathrm{NO}_{x}$ is approximately 10 days (see Figure 7). The enhancement of $\mathrm{NO}_{x}$ from lightning is transported from the continents over the oceans, producing a maximum increase of $250 \mathrm{pptv}$ in the $\mathrm{NO}_{x}$ mixing ratio over the oceans (see left panels of Plate 2). Because at this altitude the recycling of $\mathrm{NO}_{x}$ from $\mathrm{PAN}$ and $\mathrm{HNO}_{3}$ is very small (see nght panels of Plate 2), the large increase in $\mathrm{NO}_{x}$ is mainly due to the direct release of $\mathrm{NO}_{\mathrm{r}}$ from lightning (fresh $\mathrm{NO}_{x}$ ). However. in the lower troposphere. where the chemical lifetime of PAN drops less than 1 day (see Figure 7), the recycling of $\mathrm{NO}_{x}$ from $\triangle P A N$ becomes the dominant process, and produces 2 to 10 pptv over the oceans (not shown). This enhancement of $\mathrm{NO}_{x}$ over the oceans can partially explain the $\mathrm{NO}_{\mathrm{r}}$ mixing ratio of typically 10-50 pptv observed over the tropical oceans [Carroll and Thompson, 1995].

\section{Summary}

Our model calculations reveal that the concentrations of all nitrogen species are significantly affected by lightning emissions of NO. In most cases the enhancement in the nitrogen species occurs most importantly as an increase in $\mathrm{HNO}_{3}$, accounting for 70 to $80 \%$ of the increase in total nitrogen. The chemical conversion of $\mathrm{NO}_{r}$ to $\mathrm{HNO}_{3}$ occurs rapidly in the lower troposphere of the tropics. As a result, the enhancement of $\mathrm{NO}_{x}$ from direct lightning emussion is confined manly to the upper troposphere. The conversion between $\mathrm{NO}_{x}$ and less reactive nitrogen species (PAN and $\mathrm{HNO}_{3}$ ) also plays an important role in affecting $\mathrm{NO}_{x}$, especially in the free troposphere far away from lightning sources. The model results suggest that the recycling of $\mathrm{NO}_{x}$ from the enhanced PAN and $\mathrm{HNO}_{3}$ produces 2 to $10 \mathrm{pptv}$ increases in $\mathrm{NO}_{x}$ over the tropical oceans. In the middle troposphere (500 mbar), it contributes approximately $50 \%$ of the increase of $\mathrm{NO}_{x}$ from lightning.

Acknowledgments. The authors are grateful to Anne Smith, Andy Weinheimer. and two anonymous reviewers for useful comments on the manuscript. The work of $\mathrm{X}$. Tie and $\mathrm{G}$. Brasseur was partially supported by the DOE Atmosphenc Chemistry Program under contract DE-AI0598ER62579. R. Zhang and $W$. Lei were supported by the NASA New Investigator Program. The National Center for Atmospheric Research is operated by the University Corporation for Atmospheric Research under the sponsorship of the National Science Foundation.

\section{References}

Biazar, A. P., and R. T. McNider, Regional estimates of lightning production of nitrogen oxides, $J$ Geophys. Res., 100, 22,861-22,874, 1995.

Brasseur, G. P., J. F. Müller, and C. Granier, Atmospheric impact of NO emission by subsonic aircraft: A three-dimensional model study, $J$. Geophys. Res., 101, 1423-1428, 1996.

Brasseur, G. P., D. A. Hauglustaine, S. Walters, P. J. Rasch, J.-F. Müller C. Granier, and X. X. Tie, MOZART, a global chemical transport model for ozone and related chemical tracers, 1 , Model description, $J$. Geophys. Res., 103, 28,265-28,289, 1998

Carroll, M. A., and A. M. Thompson, NO in the non-urban troposphere, in Progress and Problems in Atmospheric Chemistry, edited by $\mathrm{J}$. Baker, 198-255. World Sci., River Edge, N. J., 1995.

Crutzen, P. J., The influence of nitrogen oxides on the atmospheric ozone content, Q. J. R. Meteorol. Soc., 96, 320-327, 1970.

Ehhalt. D. H., F. Rohrer, and A. Wahner, Sources and distributions of $\mathrm{NO}_{x}$ in the upper troposphere at northem midlatitude, J. Geophys. Res., $97,3725-3738,1992$.
Emmons, L. K., et al., Climatologies of $\mathrm{NO}_{x}$ and $\mathrm{NO}_{3}$ : A comparison of data and models, Atmos. Environ., 31, 1851-1903, 1997.

Emmons. L. K., D. A. Hauglustaine, J.-F. Muller, M. A. Carroll, G. P. Brasseur, D. Brunner, J. Staehelin, V. Thouret, and A. Marenco, Data composites of airbome observations of tropospheric ozone and its precursors, J. Geophys. Res., 105, 20,497-20,538, 2000

Franzblau, E.. and R. R. Popp, Nitrogen oxides produced from lightning, J. Geophys. Res., 94, 11,089-11.104, 1989

Hack, J. J., Parameterization of moist convection in the NCAR community climate model (CCM2), J. Geophys. Res., 99, 5551-5568, 1994.

Holtslag, A., and B. A. Boville, Local versus nonlocal boundary-layer diffusion in a global climate model, $J$ Clim., 6, 1825-1842, 1993.

Huntrieser, $\mathrm{H}$., et al., Transport and production of $\mathrm{NO}_{\tau}$ in electrified thunderstorms: Survey of previous studies and new observations at midlatitudes, J Geophys. Res., I03, 28,247-28,264, 1998.

Lamarque, J. F., G. P. Brasseur, P. G Hess, and J. F. Müller, Threedimensional study of the reactive contributions of the different nitrogen sources in the troposphere, J. Geophys. Res., 101. 22,955$22,968,1996$.

Levine, J. S.. Simultaneous measurements of $\mathrm{NO}_{x}, \mathrm{NO}$, and $\mathrm{O}_{3}$ production in a laboratory discharge: Atmospheric implications, Geophys Res. Lett, 8, 357-360. 1981.

Liaw, Y P., D L. Sisterson, and N L. Miller, Comparison of field. laboratory, and theoretical estimates of global nitrogen fixation by lightning, J. Geophys. Res., 95, 22,489-22,494, 1990

Nesbitt. S W.. R. Zhang, and R. E. Orville. Seasonal and global NO production by lightning estimated from the optical transient detector (OTD), Tellus, in press, 2000

Pıckering, K E.. Y. S Wang, W K. Tao. C. Price, and J. F. Muiller, Vertical distributions of lightnıng $\mathrm{NO}_{\mathrm{r}}$ for use in regional and global chemical transport model, J. Geophys Res., 103, 31,203-31,216. 1998

Price, C., J Penner, and M. Prather. NO, from lightning, 1, Global distributıon based on lightning physics, J. Geophys. Res., 102, 5929 5941.1997

Rasch, P J. and J. E. Kristjansson, A comparison of the CCM3 model climate using diagnosed and predicated condensate parameterization. J. Clim., 11, 1587-1614, 1998

Rasch, P J , and D. L. Williamson, Computational aspects of moisture transport in global models of the atmosphere, $Q$. J. R. Meteorol. Soc., $116,1071-1090,1991$.

Rıdley. B A., J. E. Dye. J. G. Walega, J. Zheng, F. E. Grahek, and W. Rison, On the production of active nitrogen by thunderstorms over New Mexico, J. Geophys. Res, 101, 20,985-21.005, 1996.

Seinfeld, J. H., and S. N. Pandis. Atmosphertc Chemistry and Physics, John Wiley. New York, 1998.

Singh. H. B , Reactive nitrogen in the troposphere. Environ. Sci. Technol., $21.320-327,1987$.

Stıth. J., J. Dye, B. Ridley, P. Laroche, E. Defer, K. Baumann, G. Hubler, and $\mathrm{R}$. Venticinque, NO signature from lightning flashes, $J$. Geophys. Res., 104, 16,081-16,089, 1999.

World Meteorological Organization (WMO), Scientific assessment of ozone depletion: 1994, Rep. 37, Global Ozone Res. and Monit. Proj., Geneva. 1995.

Zhang, R., N. T. Sanger. R. E. Orville, X. X. Tie, W. Randel, and E. R. Williams, Enhanced $\mathrm{NO}_{\mathrm{r}}$ by lightning in the upper troposphere and lower stratosphere inferred from the UARS global $\mathrm{NO}_{2}$ measurements, Geophys. Res. Lett., 27, 685-688, 2000.

G. Brasseur, L. Emmons, and X. Tie, National Center for Atmospheric Research, Boulder, CO 80307. (xxtie@ucar.edu)

W. Lei and R. Zhang, Department of Atmospheric Sciences, Texas A\&M Unıversity, College Station, TX 77843.

(Received May 17, 2000; revised August 24, 2000;

accepted September 5, 2000.) 